\title{
PENGARUH INFLASI, BI RATE DAN NILAI KURS DOLLAR AS TERHADAP INDEKS HARGA SAHAM GABUNGAN (IHSG) YANG TERDAFTAR DI BURSA EFEK INDONESIA (BEI)
}

\section{THE EFFECT OF INFLATION, BI RATE AND US DOLLAR EXCHANGE RATE ON THE COMPOSITE STOCK PRICE INDEX (IHSG) LISTED IN INDONESIA STOCK EXCHANGE (IDX)}

\author{
Syawitri Wulandari ${ }^{1}$, Sonia Angella Hutabarat ${ }^{2}$, Teresia Sihombing $^{3}$, \\ Michael Simanjuntak ${ }^{4}$, Rafida Khairani ${ }^{5}$ \\ Universitas Prima Indonesia ${ }^{1,2,3,4}$ \\ syawitriwulandari@gmail.com ${ }^{1}$
}

\begin{abstract}
This study aims to test either simultaneously or partially. The Effect of Inflation, BI Rate and US Dollar Exchange Value on the Composite Stock Price Index listed on the Indonesia Stock Exchange in the period 2008 - 2018. Using multiple linear regression analysis method to test classical assumptions such as normality, multicollinearity, autocoleration and heteroscedasticity. The results of the $F$ test study showed that the value of Fcount was 9.734> Ftable 4.35 with a significant value of $0.007<0.005$, so that inflation, BI Rate and Exchange Rate together have a significant and significant effect on the Composite Stock Price Index. In the t test, the inflation variable has no and significant effect on the Composite Stock Price Index, the BI Rate has a negative and significant effect on the Composite Stock Price Index and the Exchange Value has a positive and significant effect on the Composite Stock Price Index. With this the coefficient of determination can be seen from the Adjusted $R$ Square value of 0.724 . This means that the independent variable can explain the dependent variable by $72.4 \%$, while the remaining $27.6 \%$ is explained by other variables not examined.
\end{abstract}

Keywords: BI Rate, IHSG, Inflation, US Dollar Exchange Rate

\begin{abstract}
ABSTRAK
Penelitian ini bertujuan menguji baik secara simultan ataupun parsial. Pengaruh Inflasi, BI Rate dan Nilai Kurs Dollar AS terhadap Indeks Harga Saham Gabungan yang terdaftar di Bursa Efek Indonesia pada periode 2008 - 2018. Dengan metode analisis regresi linear berganda untuk menguji asumsi klasik seperti normalitas, multikolinieritas, autokolerasi dan heteroskedastisitas. Hasil dari penelitian uji $\mathrm{F}$ diperoleh bahwa nilai Fhitung sebesar 9,734 >Ftabel 4,35 dengan nilai signifikan sebesar $0,007<0,005$ maka Inflasi, BI Rate dan Nilai Kurs secara bersama-sama berpengaruh dan signifikan terhadap Indeks Harga Saham Gabungan. Pada uji t variabel Inflasi tidak berpengaruh dan signifikan terhadap Indeks Harga Saham Gabungan, BI Rate berpengaruh negative dan siginifikan terhadap Indeks Harga Saham Gabungan dan Nilai Kurs berpengaruh positif dan signifikan terhadap Indeks Harga Saham Gabungan. Dengan ini nilai koefisien determinasi di lihat dari nilai Adjusted R Square sebesar 0,724 . Artinya bahwa variabel bebas dapat menjelaskan variabel terikat sebesar $72,4 \%$ sedangkan sisanya $27,6 \%$ dijelaskan oleh variabel lainnya yang tidak diteliti.
\end{abstract}

Kata Kunci: BI Rate, IHSG, Inflasi, Kurs Dollar AS 


\section{PENDAHULUAN}

Sebagai mekanisme transmisi kebijakan moneter. Dimasa sekarang ini kenaikan harga saham suatu perusahaan ikut andil dalam perekonomian nasional dimana indeks harga saham dapat mempengaruhi pergerakan harga saham. Dan perubahan nilai kurs mata uang dunia. Yang dimana jika nilai kurs mata uang mengalami kenaikan maka akan berdampak pada meningkatnya tingkat suku bunga. Faktor yang mempengaruhi kuat atau lemahnya nilai suatu mata uang salah satunya adalah kegiatan ekspor dan impor.

Oleh sebab itu indeks harga saham menjadi acuan bagi investor untuk menanamkan modalnya di perusahaan. Dimana jika perusahaan mendapatkan keuntungan yang lebih secara otomatis maka perusahaan dapat membayar dividen kepada pemegang saham dengan lancar. Apabila perusahaan dapat memberikan dividen yang besar kepada pemegang saham maka investor akan tertarik menanamkan modalnya.

Investor akan cenderung melepas sahamnya jika terjadi peningkatan inflasi, dan menyebabkan harga saham turun. Makin tinggi suku bunga, maka keinginan masyarakat untuk melakukan investasi menjadi semakin kecil (Sunariah \& Kasnadi 2014). Hal ini karena penggunaan dana menjadi semakin mahal dan sebaliknya makin rendah tingkat suku bunga maka keinginan untuk melakukan investasi akan semakin meningkat. Dan penguatan kurs rupiah terhadap mata uang asing maka akan banyak investor berinvestasi pada saham. Hal ini dapat berpengaruh terhadap pembelian saham dan harga saham dalam negeri yang meningkat.

Berdasarkan tabel yang dipaparkan pada lampiran, dapat dilihat bahwa yang terjadi pada tahun 2009 tingkat Inflasi sebesar $2,78 \%$ mengalami kenaikan pada tahun 2010 menjadi 6,96\%. Tetapi pada Indeks Harga Saham Gabungan pada tahun 2009 sebesar Rp 2.534,36 mengalami kenaikan pada tahun 2010 menjadi Rp 3.703,51. Pada tahun 2011 tingkat Inflasi sebesar $3,79 \%$ mengalami kenaikan pada tahun 2012 menjadi 4,30\%. Tetapi pada Indeks Harga Saham Gabungan pada tahun 2011 sebesar Rp 3.821,49 mengalami kenaikan pada tahun 2012 menjadi Rp 4.316,69. Pada tahun 2014 tingkat Inflasi sebesar $8,36 \%$ mengalami penurunan pada tahun 2015 menjadi $3,35 \%$. Tetapi pada Indeks Harga Saham Gabungan pada tahun 2014 sebesar $\mathrm{Rp}$ 5.226,95 mengalami penurunan pada tahun 2015 menjadi Rp 4.593,00. Pada tahun 2016 tingkat Inflasi sebesar $3,02 \%$ mengalami kenaikan pada tahun 2017 menjadi $3,61 \%$. Tetapi pada Indeks Harga Saham Gabungan pada tahun 2016 sebesar Rp 5.296,71 mengalami kenaikan pada tahun 2017 menjadi Rp 6.455,65. Pada tahun 2017 tingkat Inflasi sebesar $3,61 \%$ mengalami penurunan pada tahun 2018 menjadi $3,13 \%$. Tetapi pada Indeks Harga Saham Gabungan pada tahun 2017 sebesar Rp 6.355,65 mengalami penurunan pada tahun 2018 menjadi Rp 5.931,28. Keadaan ini menunjukkan bahwa Kenaikan Inflasi tidak diikuti dengan penurunan Indeks Harga Saham Gabungan.

Pada tahun 2010 BI Rate sebesar $6,50 \%$ mengalami kenaikan pada tahun 2011 menjadi 6,58\%. Tetapi pada Indeks Harga Saham Gabungan pada tahun 2010 sebesar Rp 3.703,51 mengalami kenaikan pada tahun 2011 menjadi Rp 3.821,49. Pada tahun 2013 BI Rate sebesar 6,48\% mengalami kenaikan pada tahun 2014 menjadi $7,54 \%$. Tetapi pada Indeks Harga 
Saham Gabungan pada tahun 2013 sebesar Rp 4.274,18 mengalami kenaikan pada tahun 2014 sebesar Rp 5.226,95. Pada tahun 2014 BI Rate sebesar $7,54 \%$ mengalami penurunan pada tahun 2015 menjadi 7,52\%. Tetapi pada Indeks Harga Saham Gabungan pada tahun 2014 sebesar $\mathrm{Rp}$ 5.226,95 mengalami penurunan pada tahun 2015 menjadi Rp 4.593,00. Keadaan ini menunjukkan bahwa kenaikan BI Rate tidak diikuti dengan penuruanan Indeks Harga Saham Gabungan.

Pada tahun 2008 Nilai Kurs Dollar AS sebesar Rp 10.950 mengalami penurunan pada tahun 2009 menjadi Rp 9.400. Tetapi pada Indeks Harga Saham Gabungan pada tahun 2008 sebesar Rp 1.355,41 mengalami kenaikan pada tahun 2009 menjadi Rp 2.534,36. Pada tahun 2009 Nilai Kurs Dollar AS sebesar Rp 9.400 mengalami penurunan pada tahun 2010 menjadi Rp 8.991. Tetapi pada Indeks Harga Saham Gabungan pada tahun 2009 sebesar Rp 2.534,36 mengalami kenaikan pada tahun 2010 menjadi Rp 3.703,51. Pada tahun 2012 Nilai Kurs Dollar AS sebesar Rp 9.670 mengalami kenaikan pada tahun 2013 menjadi Rp 12.189. Tetapi pada Indeks Harga Saham Gabungan 2012 sebesar Rp 4.316,69 mengalami penurunan pada tahun 2013 menjadi Rp 4.274,18. Pada tahun 2014 Nilai Kurs Dollar AS sebesar Rp 12.440 mengalami kenaikan pada tahun 2015 menjadi Rp 13.795. Tetapi pada Indeks Harga Saham Gabungan pada tahun 2014 sebesar Rp 5.226,95 mengalami penurunan pada tahun 2015 menjadi Rp 4.593,00. Pada tahun 2015 Nilai Kurs Dollar AS sebesar Rp 13.795 mengalami penurunan pada tahun 2016 menjadi Rp 13.436. Tetapi pada Indeks Harga Saham Gabungan pada tahun 2015 sebesar Rp 4.593,00 mengalami kenaikan pada tahun 2016 menjadi Rp 5.296,71. Pada tahun 2017 Nilai Kurs Dollar AS sebesar Rp 13.548 mengalami kenaikan pada tahun 2018 menjadi Rp 14.481. Tetapi pada Indeks Harga Saham Gabungan pada tahun 2017 sebesar Rp 6.355,65 mengalami penurunan pada tahun 2018 menjadi Rp 5.931,28. Keadaan ini menunjukkan bahwa kenaikan Nilai Kurs Dollar AS tidak diikuti dengan kenaikan Indeks Harga Saham Gabungan.

\section{METODE PENELITIAN}

Dalam penelitian ini menggunakan pendekatan kuantitatif yaitu data sekunder. Dan menggunakan jenis penelitian statistik deskriptif. Populasi yang digunakan dalam penelitian ini adalah data Inflasi, BI Rate, Nilai Kurs Dollar AS dan Indeks Harga Saham Gabungan. Sedangkan sampel yang diambil adalah data selama periode 2008 - 2018 yaitu 11 tahun.

Pengambilan sampel yang dilakukan pada penelitian ini menggunakan purposive sampling, ialah salah satu teknik cara sampling dimana peneliti memutuskan pengambilan sampel dengan cara menetapkan ciri-ciri khusus yang sesuai dengan sasaran penelitian sehingga diharapkan dapat menjawab permasalahan penelitian.

Teknik pengumpulan data yang digunakan adalah metode dokumentasi. Data yang didapat berupa laporan tahunan yang terdaftar dan dipublikasikan di Badan Pusat Statistik, Bank Indonesia, Otoritas Jasa Keuangan dan Bursa Efek Indonesia. 
HASIL DAN PEMBAHASAN Statistik Deskriptif

\begin{tabular}{lrrrrr}
\multicolumn{7}{c}{ Tabel 1 Statistik Deskriptif } \\
\hline & $\mathrm{N}$ & \multicolumn{1}{c}{ Minimum } & \multicolumn{1}{c}{ Maximum } & \multicolumn{1}{c}{ Mean } & \multicolumn{1}{c}{ Std. Deviation } \\
\hline INFLASI & 11 & 278.0000 & 1106.0000 & 533.818182 & 284.3251020 \\
BI RATE & 11 & 456.0000 & 867.0000 & 653.363636 & 117.1616599 \\
NILAI KURS & 11 & 8.9910 & 14.4810 & 11.633455 & 2.0863677 \\
IHSG & 11 & 1355.4100 & 6355.6500 & 4309.930000 & 1455.9538138 \\
Valid N (listwise) & 11 & & & & \\
\hline
\end{tabular}

Sumber: Data diolah (SPSS 23), 2020

Berdasarkan Tabel.I diatas, maka dapat diketahui bahwa Inflasi terendah yaitu $2,78 \%$ pada tahun 2009 dan tertinggi $11,06 \%$ pada tahun 2008 . Hasil tersebut menunjukkan bahwa besarnya Inflasi yang menjadi sampel penelitian berkisar antara 2,78\% sampai $11,06 \%$ dengan nilai mean 533.818182 dengan standar deviasi 284.3251020.

Berdasarkan hasil pengujian tersebut diketahui bahwa BI Rate terendah yaitu $4,56 \%$ pada tahun 2017 dan tertinggi $8,67 \%$ pada tahun 2008 . Hasil tersebut menunjukkan bahwa besarnya $B I$ Rate yang menjadi sampel penelitian ini berkisar antara 4,56\% sampai $8,67 \%$ dengan nilai mean 653.363636 dengan standar deviasi 117.1616599.

Berdasarkan hasil pengujian tersebut diketahui bahwa Nilai Kurs terendah yaitu $\mathrm{Rp} 8.991$ pada tahun 2010 dan tertinggi Rp 14.481 pada tahun 2018. Hasil tersebut menunjukkan bahwa besarnya Nilai Kurs yang menjadi sampel penelitian ini berkisar antara Rp 8.991 sampai Rp 14.481 dengan nilai mean 11.633455 dengan standar deviasi 2.0863677.

Berdasarkan hasil pengujian tersebut diketahui bahwa Indeks Harga Saham Gabungan terendah yaitu $\mathrm{Rp}$ $1.355,41$ pada tahun 2008 dan tertinggi Rp 6.355,65 pada tahun 2017. Hasil tersebut menunjukkan bahwa besarnya Indeks Harga Saham Gabungan yang menjadi sampel penelitian ini berkisar antara $\mathrm{Rp} 1.355,41$ sampai $\mathrm{Rp} 6.355,65$ dengan nilai mean 4309.930000 dengan standar deviasi 1455.9538138.

\section{Uji Analisis Regresi Linear Berganda} Regresi linier berganda merupakan pengembangan dari regresi linier sederhana yang dapat digunakan untuk mengetahui pengaruh satu atau lebih variabel bebas terhadap satu variabel terikat.

Tabel 2. Analisis Regresi Linear Berganda

Coefficients $^{\mathrm{a}}$

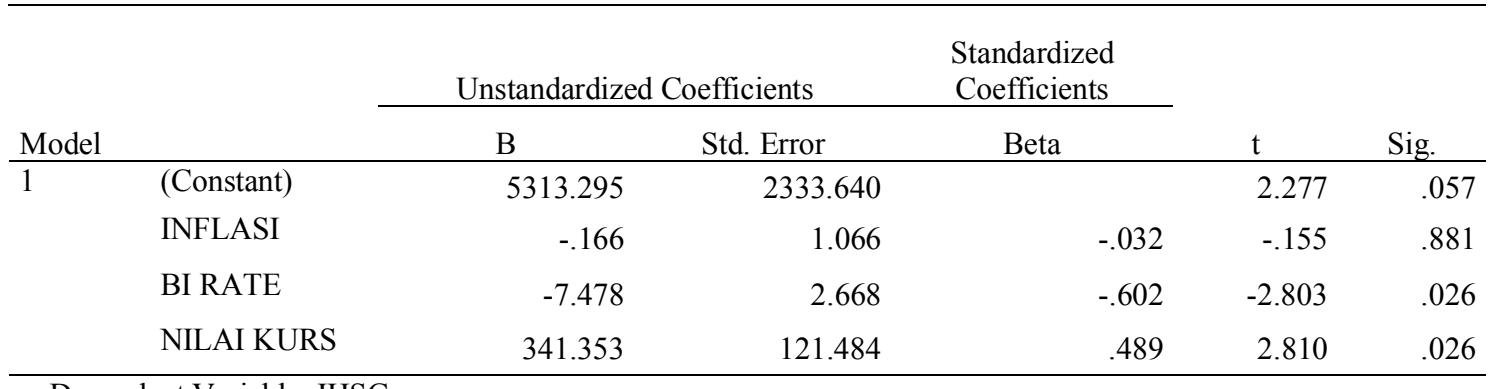

a. Dependent Variable: IHSG

Sumber: Data diolah (SPSS 23), 2020 
Dengan memperlihatkan model regresi dan hasil regresi linear berganda maka didapat persamaan factor-faktor yang mempengaruhi Indeks Harga Saham Gabungan sebagai berikut;

$\mathrm{Y}=\mathrm{a}-\mathrm{b}_{1} \mathrm{X}_{1}-\mathrm{b}_{2} \mathrm{X}_{2}+\mathrm{b}_{3} \mathrm{X}_{3}+\mathrm{e}$

$Y=5313,295-0,166$ Inflasi $-7,478$

BI Rate + 341,353 Nilai Kurs + e

Berdasarkan persamaan diatas dapat dilakukan interpretasi sebagai berikut :

1. $\mathrm{a}=5313,295$ artinya jika nilai Inflasi $\left(\mathrm{X}_{1}\right)$, BI Rate $\left(\mathrm{X}_{2}\right)$, Nilai Kurs $\left(\mathrm{X}_{3}\right)$ maka Indeks Harga Saham Gabungan (Y) adalah Rp 5313,295

2. Koefisien regresi $b_{1}=-0,166$ (tidak signifikan) mempunyai arti bahwa kenaikan Inflasi sebesar 1\% akan menurunkan Indeks Harga Saham Gabungan sebesar -0,166 (faktor lain di anggap tetap), begitu juga sebaliknya.
3. Koefisien regresi $b_{2}=-7,478$ (signifikan) mempunyai arti bahwa kenaikan BI Rate sebesar $1 \%$ akan menurunkan Indeks Harga Saham Gabungan sebesar -7,478 (faktor lain di anggap tetap), begitu juga sebaliknya.

4. Koefisien regresi $b_{3}=341,353$ (signifikan) mempunyai arti bahwa kenaikan Kurs sebesar Rp 1,- akan menaikkan Indeks Harga Saham Gabungan sebesar 341,353 (faktor lain dianggap tetap), begitu juga sebaliknya.

\section{Uji Koefisien Determinasi $\left(\mathbf{R}^{2)}\right.$}

Koefisien determinasi

digunakan untuk mengukur persentase varian variabel dependen yang dapat dijelaskan oleh variabel-variabel independen. Semakin besar adjusted mendekati satu maka variabel-variabel independen memberikan hampir semua informasi yang dibutuhkan untuk memprediksi variasi variabel dependen.

Tabel 3. Uji $\mathbf{R}^{2}$

Model Summary

\begin{tabular}{lcccc}
\hline Model & $\mathrm{R}$ & R Square & $\begin{array}{c}\text { Adjusted R } \\
\text { Square }\end{array}$ & $\begin{array}{c}\text { Std. Error of the } \\
\text { Estimate }\end{array}$ \\
\hline 1 & $.898^{\mathrm{a}}$ & .807 & .724 & 765.1958686 \\
\hline a. Predictors: (Constant), NILAI KURS, INFLASI, BI RATE \\
Sumber : Data diolah (SPSS 23), 2020
\end{tabular}

Berdasarkan

pengujian menunjukkan nilai Adjusted $R$ Square $=$ 0,724 . Nilai ini menunjukkan secara bersama-sama variabel Inflasi, BI Rate dan Nilai Kurs memberikan pengaruh terhadap Indeks Harga Saham Gabungan sebesar $72,4 \%$ sedangkan sisa nya sebesar $27,6 \%$ yang dipengaruhi oleh faktor-faktor lain yang tidak dimasukkan dalam model penelitian ini.
Uji F

Uji $F$ digunakan untuk menguji bagaimana pengaruh semua variabel bebasnya secara bersama-sama terhadap variabel terikatnya atau model regresi mengalami signifikan atau tidak signifikan. Pengujian ini dilakukan dengan membandingkan nilai $\mathrm{F}_{\text {hitung }}>$ $\mathrm{F}_{\text {tabel }}, \mathrm{Sig}<0,05$ maka $\mathrm{H}_{0}$ diterima. 
Tabel 4. Uji F

\begin{tabular}{ccccccc}
\multicolumn{7}{c}{ ANOVA $^{\mathbf{a}}$} \\
\hline & Model & Sum of Squares & Df & Mean Square & F & Sig. \\
\hline \multirow{4}{*}{1} & Regression & 17099342.059 & 3 & 5699780.686 & 9.734 & $.007^{\mathbf{b}}$ \\
& Residual & 4098673.021 & 7 & 585524.717 & & \\
& Total & 21198015.080 & 10 & & & \\
\hline
\end{tabular}

a. Dependent Variable: IHSG

b. Predictors: (Constant), NILAI KURS, INFLASI, BI RATE

Sumber: Data diolah (SPSS 23) 2020

Nilai $F$ hitung pada penelitian ini adalah 9,734, angka tersebut lebih besar dari nilai $F$ table sebesar 4,35 dan dengan taraf signifikasi sebesar 0,007 lebih kecil dari $\alpha \quad 0,05$ maka disimpulkan bahwa terdapat pengaruh yang signifikan antara Inflasi , BI Rate, Nilai Kurs secara simultan terhadap Indeks Harga Saham Gabungan yang berarti $\mathrm{H}_{0}$ diterima.

\section{Uji - t}

Uji $\mathrm{t}$ digunakan untuk mengetahui signifikansi pengaruh variabel independen secara parsial terhadap variabel dependen. Pengujian ini dilakukan dengan membandingkan

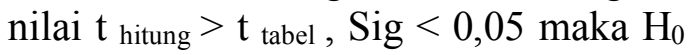
diterima.

Tabel 5. Uji t

Coefficients $^{\mathrm{a}}$

\begin{tabular}{|c|c|c|c|c|c|c|}
\hline \multirow[b]{2}{*}{ Model } & & \multicolumn{2}{|c|}{ Unstandardized Coefficients } & $\begin{array}{l}\text { Standardized } \\
\text { Coefficients }\end{array}$ & \multirow[b]{2}{*}{$\mathrm{T}$} & \multirow[b]{2}{*}{ Sig. } \\
\hline & & $\mathrm{B}$ & Std. Error & Beta & & \\
\hline 1 & (Constant) & 5313.295 & 2333.640 & & 2.277 & .057 \\
\hline & INFLASI & -.166 & 1.066 & -.032 & -.155 & .881 \\
\hline & BI RATE & -7.478 & 2.668 & -.602 & -2.803 & .026 \\
\hline & NILAI KURS & 341.353 & 121.484 & .489 & 2.810 & .026 \\
\hline
\end{tabular}

a. Dependent Variable: IHSG

Sumber : Data diolah (SPSS 23), 2020

Nilai $\mathrm{t}$ hitung Inflasi sebesar 0,155 nilai ini lebih kecil dari nilai $\mathrm{t}$ tabel sebesar 2,36462 dengan nilai signifikansi 0,881 lebih besar dari $\alpha$ 0,05 . Hal ini menunjukkan bahwa variabel Inflasi tidak berpengaruh signifikan secara parsial terhadap variabel Indeks Harga Saham Gabungan.

Nilai t hitung BI Rate sebesar 2,803 nilai ini lebih besar dari nilai $t$ tabel sebesar 2,36462 dengan nilai signifikansi 0,026 lebih kecil dari $\alpha$ 0,05 . Hal ini menunjukkan bahwa variabel BI Rate berpengaruh negatif signifikan secara parsial terhadap variabel Indeks Harga Saham Gabungan.
Nilai $\mathrm{t}$ hitung Nilai Kurs sebesar 2,810 nilai ini lebih besar dari nilai $\mathrm{t}$ table sebesar 2,36462 dengan nilai signifikansi 0,026 lebih kecil dari $\alpha$ 0,05 . Hal ini menunjukkan bahwa variabel Nilai Kurs berpengaruh positif signifikan secara parsial terhadap Indeks Harga Saham Gabungan.

Hasil analisis menunjukkan bahwa Inflasi negatif tidak berpengaruh $\left(b_{1}=-0,166\right)$ dan tidak signifikan (sig $=0,010)$ terhadap Indeks Harga Saham Gabungan. Sehingga dapat di interpretasikan bahwa kenaikan Inflasi sebesar $1 \%$ akan menurunkan Indeks Harga Saham Gabungan sebesar -0,166, begitu juga sebaliknya. Hasil penelitian ini sesuai dengan hasil penelitian Appa (2014) yang mengatakan bahwa Inflasi 
tidak berpengaruh dan signifikan terhadap Indeks Harga Saham Gabungan (IHSG).

Hasil analisis menunjukkan bahwa BI Rate negatif berpengaruh $\left(b_{2}\right.$ $=-2,803)$ dan signifikan $(\mathrm{sig}=0,010)$ terhadap Indeks Harga Saham Gabungan. Sehingga dapat di interpretasikan bahwa kenaikan BI Rate sebesar 1\% akan menurunkan Indeks Harga Saham Gabungan sebesar 2,803, begitu juga sebaliknya. Hasil penelitian ini sesuai dengan hasil penelitian Sunardi \& Ula (2017) yang mengatakan bahwa BI Rate berpengaruh negatif dan signifikan terhadap Indeks Harga Saham Gabungan (IHSG).

Hasil analisis menunjukkan bahwa Nilai Kurs positif berpengaruh $\left(b_{3}=2,810\right)$ dan signifikan $(\operatorname{sig}=0,010)$ terhadap Indeks Harga Saham Gabungan. Sehingga dapat di interpretasikan bahwa kenaikan Nilai Kurs sebesar 1\% akan menaikkan Indeks Harga Saham Gabungan sebesar 2,803, begitu juga sebaliknya. Hasil penelitian ini sesuai denga hasil penelitian Taufiq \& Kefi (2015) mengatakan bahwa Nilai Kurs berpengaruh positif dan signifikan terhadap Indeks Harga Saham Gabungan (IHSG).

Pada pengujian untuk keseluruhan variabel dalam model dilakukan menggunakan uji F. Hasil menunjukkan nilai $F$ hitung sebesar 9,734 dengan nilai $\mathrm{F}$ tabel nya sebesar 4,35 dan nilai sig $0,007<0,05$ yang berarti $\mathrm{H}_{0}$ positif dan signifikan. Demikian variabel Inflasi, BI Rate dan Nilai Kurs diproaksikan secara bersama-sama (simultan) berpengaruh positif dan signifikan terhadap Indeks Harga Saham Gabungan. Hasil penelitian ini sesuai dengan hasil penelitian Sunardi \& Ula (2017) yang mengatakan bahwa Inflasi, BI Rate dan
Nilai Kurs secara bersama-sama (simultan) berpengaruh positif dan signifikan terhadap Indeks Harga Saham Gabungan (IHSG).

Untuk pengujian koefisien determinasi $\left(\mathrm{R}^{2}\right)$ menunjukkan angka sebesar 0,724 artinya bahwa variasi perubahan naik turunnya Indeks Harga Saham Gabungan (IHSG) dapat dipengaruhi oleh Inflasi, BI Rate dan Nilai Kurs sebesar $72,4 \%$ sementara sisanya sebesar $27,6 \%$ dijelaskan oleh variabel-variabel lain diluar model penelitian ini. Untuk koefisien determinasi yang disesuaikan $\left(R^{2}\right.$ Adjusted) menunjukkan angka 0,724 yang berarti bahwa setelah mempertimbangkan derajat kebebasan model yang digunakan dalam penelitian ini menjelaskan Indeks Harga Saham Gabungan (IHSG) sebesar 72,4.

\section{PENUTUP \\ Kesimpulan}

Berdasarkan hasil pengujian yang dilakukan berdasarkan hipotesis dan analisis pengaruh Inflasi, BI Rate dan Nilai Kurs terhadap Indeks Harga Saham Gabungan (IHSG) yang terdaftar di Bursa Efek Indonesia (BEI) selama periode 2008-2018 secara spesifik, sesuai dengan rumusan masalah, tujuan penelitian dan hipotesis penelitian, maka dapat disimpulkam sebagai berikut :

1. Pada uji $t$ variabel Inflasi tidak berpengaruh dan signifikan terhadap Indeks Harga Saham Gabungan, BI Rate berpengaruh negative dan siginifikan terhadap Indeks Harga Saham Gabungan dan Nilai Kurs berpengaruh positif dan signifikan terhadap Indeks Harga Saham Gabungan.

2. Hasil dari penelitian uji $F$ diperoleh bahwa nilai $F_{\text {hitung }}$ sebesar 9,734 $>F_{\text {tabel }}$ 4,35 dengan nilai signifikan sebesar 0,007 $<0,005$ maka Inflasi, BI Rate dan Nilai Kurs secara bersama-sama berpengaruh 
dan signifikan terhadap Indeks Harga Saham Gabungan.

3. Nilai koefisien determinasi di lihat dari nilai Adjusted $R$ Square sebesar 0,724. Artinya bahwa variabel bebas dapat menjelaskan variabel terikat sebesar $72,4 \%$ sedangkan sisanya $27,6 \%$ dijelaskan oleh variabel lainnya yang tidak diteliti.

4. Pada analisis linear berganda maka didapat persamaan faktor-faktor yang mempengaruhi Indeks Harga Saham Gabungan yaitu $Y=5313,295-0,166$ Inflasi - 7,478 BI Rate + 341,353 Nilai Kurs + e.

\section{Saran}

Saran yang dapat diberikan berdasarkan hasil dari penelitian ini adalah sebagai berikut:

1. Penelitian mengenai variabel yang dapat mempengaruhi Indeks Harga Saham Gabungan (IHSG) dapat dilakukan pengembangan kembali dengan menggunakan variabel independen lain serta menggunakan variabel dependen pengembangan dari berbagai macam indeks lainnya.

2. Peneliti selanjutnya sebaiknya memperpanjang periode penelitian, sehingga akan diperoleh gambaran yang lebih baik tentang kondisi pasar modal di Indonesia.

\section{DAFTAR PUSTAKA}

Appa, Y. (2014). Pengaruh Inflasi dan Kurs Rupiah/Dolar Amerika Terhadap Indeks Harga Saham Gabungan (IHSG) di Bursa Efek Indonesia (BEI). Jurnal ISSN, 2355-5408.

Sunariah, K., \& Kasmadi, N. (2014). Panduan Modern Penelitian Kuantitatif. Bandung: Alfabeta.

Sunardi, N., \& Ula, L. N. R. (2017). Pengaruh BI Rate, Inflasi dan Kurs Terhadap Indeks Harga Saham Gabungan (IHSG). Jurnal Sekuritas: Saham, Ekonomi, Keuangan dan Investasi, 1(2), 27-41.

Taufiq, M., \& Kefi, B. S. (2015). Pengaruh inflasi, BI rate dan kurs terhadap indeks harga saham gabungan. Jurnal Ekonomi Manajemen Akuntansi, 22(38). 